\title{
Analisis kinerja kegiatan rehabilitasi hutan dan lahan berdasarkan value for money
}

\author{
Novia Nurdia Ningsih ${ }^{1}$, Siti Masyithoh ${ }^{2}$, Ibnu Abni Lahaya ${ }^{3}$ \\ Fakultas Ekonomi dan Bisnis Universitas Mulawarman, Samarinda. \\ ${ }^{1}$ Email: nurdianingsihnovia@gmail.com \\ 2Email: siti.masyithoh@feb.unmul.ac.id \\ ${ }^{3}$ Email: ibnu.abni.lahaya@feb.unmul.ac.id
}

\begin{abstract}
Abstrak
Penelitian ini merupakan penelitian deskriptif kualitatif atas Realisasi Pencapaian Keuangan Dinas Kehutanan Provinsi Kalimantan Timur Kota Samarinda yang terdapat pada Laporan Akuntabilitas Kinerja Instansi Pemerintah (LAKIP) Dinas Kehutanan Provinsi Kalimantan Timur Kota Samarinda periode tahun 2014. Metode pengumpulan data yang digunakan adalah dokumentasi dan Penelitian Lapangan. Berdasarkan hasil analisis yang diperoleh yaitu Nilai Ekonomi dari Program Kegiatan Rehabilitasi Hutan dan Lahan yang dilakukan Dinas Kehutanan Provinsi Kalimantan Timur dapat diukur dengan membandingkan input primer (dana yang terealisasi) dengan input sekunder berupa (SDM/Tim Pengadaan Saran dan Prasarana). Dari hasil perhitungan analisis Kertas Kerja Penilaian Kinerja Dinas Kehutanan Provinsi Kalimantan Timur memperoleh nilai ekonomi sebesar 89\%. Nilai Kinerja Ekonomi $85 \%$ sampai dengan $100 \%$ merupakan nilai kinerja yang masuk pada kategori Cukup Ekonomis. Berdasarkan hasil analisis data pengukuran efisiensi pada program kegiatan Rehabilitasi Hutan dan Lahan diketahui bahwa untuk periode tahun 2014 program kegiatan ini dapat dikatakan efisien. Dari hasil perhitungan analisis Kertas Kerja Penilaian Kinerja Value For Money Dinas Kehutanan Provinsi Kalimantan Timur memperoleh nilai efisiensi sebesar 130\%. Rasio efektivitas yang dihasilkan kegiatan ini pada periode tahun 2014 menurut Kertas Kerja Penilaian Value For Money yaitu $96,55 \%$. Dengan membandingkan anatara nilai kinerja dibagi dengan nilai kinerja output maka pendapatkan persentase tersebut.
\end{abstract}

Kata Kunci: Ekonomi; Efisiensi dan efektivitas

\section{Analysis of the performance of forest and land rehabilitation activities based on value for money}

\begin{abstract}
This research is a qualitative descriptive study on the Realization of Financial Achievement of East Kalimantan Province Forestry Office of Samarinda City which is contained in Government Agency's Performance Accountability Report (LAKIP) Forest Service of East Kalimantan Province of Samarinda City in 2014. Data collection method used is documentation and Field Research. Based on the analysis obtained, the Economic Value of Forest and Land Rehabilitation Program conducted by East Kalimantan Provincial Forestry Office can be measured by comparing the primary input (realized fund) with secondary input (HR / Suggestion and Infrastructure Team). From the calculation of the analysis of Performance Assessment Paper of East Kalimantan Provincial Forestry Service obtained economic value of $89 \%$. Economic Performance Value $85 \%$ to $100 \%$ is the value of the performance that entered in the category Economic Self. Based on the results of the analysis of efficiency measurement data on Forest and Land Rehabilitation program is known that for the period of 2014 this activity program can be said to be efficient. From the calculation results of Value Working Assessment Working Paper Value For Money East Kalimantan Provincial Forestry Service obtained an efficiency value of $130 \%$. The effectiveness ratio generated by this activity in the period of 2014 according to Value For Money Appraisal Working Paper is $96.55 \%$. By comparing the values of performance divided by the output performance value then the percentage earners.
\end{abstract}

Keywords: Economics; Efficiency and effectiveness 


\section{PENDAHULUAN}

Lembaga Pemerintah merupakan organisasi yang diberi kekuasaan untuk mengatur kepentingan bangsa dan negara. Lembaga pemerintahan dibentuk umumnya untuk menjalankan aktivitas layanan terhadap masyarakat luas. Sebagai organisasi nirlaba, pemerintah mempunyai tujuan bukan mencari keuntungan, tetapi semata -mata untuk menyediakan layanan dan kemampuan meningkatkan layanan tersebut dimasa yang akan datang. Tujuan yang ingin dicapai biasanya ditentukan dalam bentuk kualitatif, misalnya peningkatan keamanan dan kenyamanan, mutu pendidikan, mutu kesehatan dan sebagainya.

Sektor publik sering dinilai sebagai sarang inefisiensi, pemborosan, sumber kebocoran dana, dan instusi yang selalu merugi. Tuntutan baru muncul agar organisasi sektor publik memperhatikan value for money dalam menjalankan aktivitasnya. Value for money merupakan konsep pengelolaan organisasi sektor publik yang mendasarkan pada tiga elemen utama, yaitu: ekonomi, efisiensi, dan efektivitas (Mardiasmo, 2009:4).

Dengan adanya program prioritas utama dengan tingkat presentasi yang rendah, maka perlu dilakukan penilaian kinerja (performance appraisal) yang pada dasarnya merupakan faktor kunci, guna untuk mengembangkan suatu organisasi secara ekonomi, efektif dan efisien. Penilaian kinerja individu sangat bermanfaat bagi dinamika pertumbuhan organisasi (Dinas Kehutanan Provinsi Kalimantan Timur) secara keseluruhan, karena melalui penilaian tersebut maka dapat diketahui bagaimana kondisi atau sejauh mana tingkat keberhasilan organisasi dalam melaksanakan tugas perbantuan dan kewenangan dibidang pengelolaan kehutanan. Penelitian ini difokuskan pada Kegiatan Rehabilitasi Hutan dan Lahan dengan nilai kegiatan sebesar Rp4.683.790.000 dengan tingkat keberhasilan sebesar $68,16 \%$. Kegiatan Rehabilitasi Hutan dan Lahan juga merupakan program yang sangat penting bagi masyarakat, karena merupakan program utama yang capaiannya paling rendah ditahun 2014 dengan periode pengerjaan selama 1 tahun. Kebijakan tersebut untuk menjawab permasalahan yang dihadapi oleh Daerah (Kabupaten/Kota) terkait dengan semakin terdegradasinya lingkungan, termasuk kerusakan hutan. Berkurangnya kualitas lingkungan dapat menimbulkan bencana banjir dan tanah longsor, kekeringan, tingkat abrasi yang tinggi akibat rusaknya hutan mangrove dan bencana lingkungan lainnya.

\section{Kajian Pustaka}

\section{Akuntansi Sektor Publik}

Menurut Mardiasmo (2009:141) dari sudut pandang ekonomi, sektor publik dapat dipahami sebagai entitas yang aktivitasnya berhubungan dengan usaha untuk menghasilkan barang dan pelayanan publik dalam rangka memenuhi kebutuhan dan hak publik Menurut Bastian (2009:15) akuntansi sektor publik merupakan Mekanisme teknik analisis akuntansi yang diterapkan pada pengelolaan dana masyarakat di lembaga - lembaga tinggi Negara dan departemen-departemen di bawahnya, pemerintah daerah, BUMN, BUMD, LSM, dan yayasan sosial, maupun pada proyek-proyek kerjasama sektor publik dan swasta Sedangkan menurut Abdul Halim (2008:34) didalam bukunya yang berjudul Akuntansi Keuangan Daerah, Akuntansi sektor publik ialah "Akuntansi yang datanya digunakan untuk memberikan informasi mengenai transaksi ekonomi dan keuangan pemerintah kepada pihak eksekutif, legislatif, yudikatif dan masyarakat

\section{Akuntabilitas Sektor Publik}

Penerapan akuntabilitas kinerja sektor publik di Indonesia dimulai dengan terbitnya UU No. 25 tahun 2004 tentang Sistem Perencanaan Pembangunan Nasional. UU tersebut memerintahkan SKPD pemerintahan provinsi atau kabupaten atau kota dan kementerian atau lembaga untuk menyusun rencana strategis (Renstra) dan rencana kerja. Renstra antara lainmemuat visi, misi, tujuan, strategi, kebijakan, program dan kegiatan yang sesuai dengan tugas dan fungsi kementerian atau lembaga atau SKPD Pemerintah Provinsi atau kabupaten atau kota. Fenomena yang dapat diamati dalam perkembangan sektor publik dewasa ini adalah semakin menguatnya tuntutan pelaksanaan akuntabilitas publik oleh organisasi sektor publik (seperti : pemerintah pusat dan daerah, unit-unit kerja pemerintah, departemen dan lembaga-lembaga Negara). Tuntutan akuntabilitas sektor publik terkait dengan perlunya dilakukan transparansi dan pemberian informasi kepada publik dalam rangka pemenuhan hak-hak publik. 
Akuntabilitas publik menurut Mardiasmo (2009:3) adalah sebagai bentuk kewajiban mempertanggungjawabkan keberhasilan atau kegagalan pelaksanaan misi organisasi dalam mencapai tujuan dan sasaran yang telah ditetapkan sebelumnya, melalui suatu media pertanggungjawaban yang dilaksanakan secara periodik. Akuntabilitas publik menurut Mahmudi (2015:23) adalah kewajiban agen (pemerintah) untuk mengelola sumber daya, melaporkan, dan mengungkapkan segala aktivitas dan kegiatan yang berkaitan dengan penggunaan sumber daya publik kepada pemberi mandat (principal)". Akuntabilitas pemerintahan di negara yang menganut paham demokrasi sebenarnya tidak lepas dari prinsip dasar demokrasi yaitu kedaulatan adalah di tangan rakyat dalam bernegara dengan mengeluarkan sejumlah aturan serta mengambil dan menggunakan sumber dana masyarakat. Pemerintah wajib memberikan pertanggungjawabannya atas semua akivitasnya kepada masyarakat.

\section{Kinerja}

Menurut Bastian (2009:329) kinerja merupakan gambaran mengenai tingkat pencapaian pelaksanaan suatu kegiatan atau program atau kebijakan dalam mewujudkan sasaran, tujuan, misi, dan visi organisasi yang tertuang dalam perumusan strategis (strategic planning) organisasi. Istilah kinerja sering digunakan untuk menyebut prestasi atau tingkat keberhasilan individu maupun kelompok individu tersebut mempunyai kriteria keberhasilan yang telah ditetapkan. Kriteria keberhasilan ini berupa tujuan-tujuan atau target-target tertentu yang hendak dicapai. Kinerja adalah hasil kerja secara kualitas dan kuantitas yang dicapai oleh seorang pegawai dalam melaksanakan tugasnya sesuai dengan tanggungjawab yang diberikannya kepadanya (Mangkunegara, 2009:67). Menurut Sedarmayanti (2011:260) kinerja merupakan terjemahan dari "performance" yang berarti hasil kerja seorang pekerja, sebuah proses manajemen atau suatu organisasi secara keseluruhan, dimana hasil kerja tersebut harus dapat ditunjukkan buktinya secara konkrot dan dapat diukur (dibandingkan dengan standar yang telah ditentukan) Wibowo (2010:7) menjelaskan kinerja adalah tentang melakukan pekerjaan dan hasil yang dicapai dari pekerjaan tersebut. Dari beberapa pendapat diatas, maka dapat disimpulkan bahwa pengertian kinerja dalam penelitian ini adalah suatu hasil kerja yang dicapai oleh masing-masing pegawai yang dalam pelaksanaan tugas pekerjaan berdasarkan ukuran dan waktu yang telah ditentukan guna mewujudkan tujuan organisasi.

\section{Value for Money}

\section{Definisi Value for Money}

Definisi Value For Money berdasarkan Audit Commision dalam Final Report yang disampaikan oleh ITAD, dalam jurnal berjudul Measuring the impact and Value For Money of Governance and Conflict Programmers (Chris Barnett, 2010) mengungkapkan:

"VFM is about obtaining the maximum benefit over time with the resources available. It is about achieving the right local balance between economy, efficiency and affectiveness, or, spending less, spending well and spending wisely to achieve local priorities... VFM is high when there ie an optimum balance between all three elements, when costs are relatively low, productivity is high and auccessful outcomes have been achieved". Tolak ukur dalam anggaran belanja suatu organisasi, baik organisasi berorientasi laba (swasta) maupun organisasi nonprofit (sektorpublik) adalah Value For Money yang meliputi penilaian efisiensi, efektivitas, dan ekonomi. Kinerja pemerintah tidak dapat dinilai dari sisi output yang dihasilkan saja, akan tetapi harus mempertimbangkan input, output dan outcome secara bersama-sama. Bahkan untuk beberapa hal perlu ditambahkan pengukuarn distribusi dabn cakupan layanan (equity and service coverage). Permasalahan yang sering dihadapi pemerintah dalam melakukan pengukuran kinerja adalah sulitnya mengukur output, karena output uang dihasilkan tidak selalu berupa output yang berwujud, akan tetapi lebih banyak berupa intangible output.

Menurut Mahmudi (2015:81) penialaian kinerja berdasarakan value for money adalah pengukuran kinerja untuk mengatur ekonomi, efisien, dan efektivitas suatu kegiatan, program dan organisasi. Pengukuran kinerja value for money merupakan bagian terpenting setiap pengukuran kinerja organisasi sektor publik. Karena pemerintah sebagai wakil rakyat yang dipercayakan untuk mengatur dan mengurusi rumah tangga Negara harus mempertanggungjawabkan setiap rupiah yang dikeluarkan. Penilaian kinerja dilakukan untuk mengatur sampai sejauh mana akuntabilitas pemerintah dalam membelanjakan dana publik apakah telah memenuhi prinsip ekonomi, efisiensi dan efektifitas. 


\section{Elemen-elemen Value for Money}

Value for money merupakan konsep pengelolaan organisasi sektor publik yang mendasarkan pada tiga elemen utama. Secara skematis hubungan value for money dapat dilihat pada gambar 2.1 yaitu sebagai berikut:

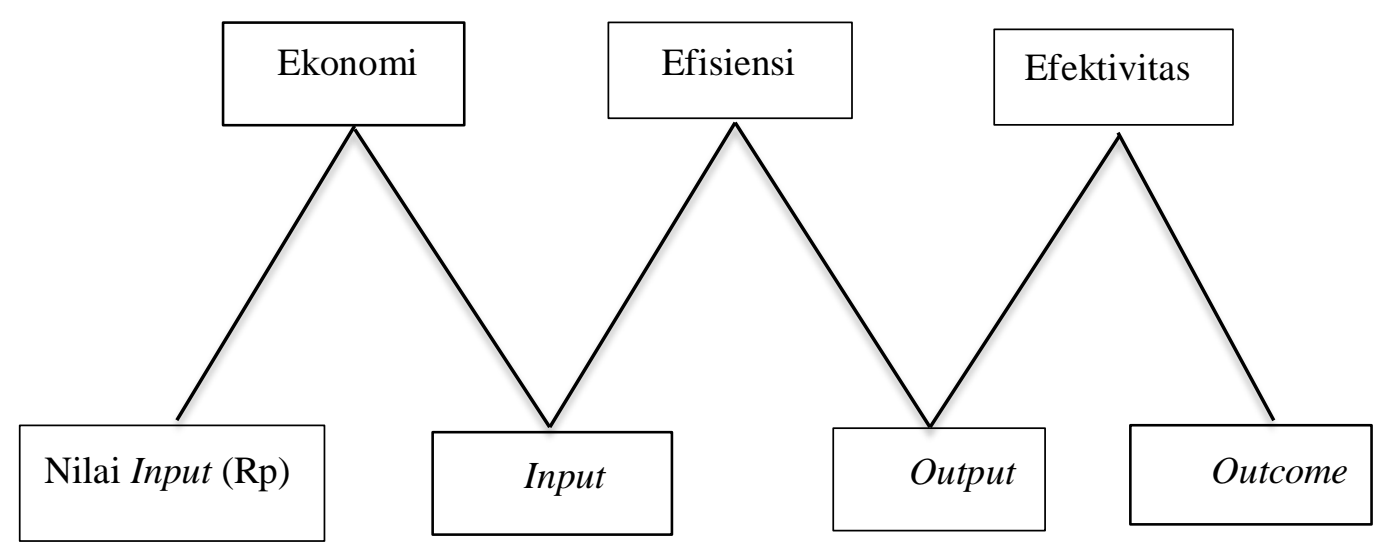

Gambar 1. Value For Money

Sumber: Akuntansi Sektor Publik (Mardiasmo, 2009:5)

Dari gambar 1 mengenai value for money dapat di jelaskan secara terperinci (Mahmudi, 2015:84) yaitu sebagai berikut:

1) Ekonomi

Ekonomi terkait dengan pengkonversian input primer berupa sumber daya keuangan (uang/kas) menjadi input sekunder berupa tenaga kerja, bahan, infrastruktur, dan barang modal yang dikonsumsi untuk kegiatan operasi organisasi. Konsep ekonomi sangat terkait dengan konsep biaya untuk memperoleh unit input. Ekonomi memiliki pengertian bahwa sumber daya input hendaknya diperoleh dengan harga lebih (spending less), yaitu harga yang mendekati harga pasar.

2) Efisien

Jika ekonomi hanya berbicara mengenai input, yaitu bagaimana memperoleh input dengan biaya atau harga lebih rendah, maka efisiensi berbicara mengenai input dan output. Efisiensi terkait dengan hubungan antara output berupa barang atau pelayanan yang dihasilkan dengan sumber daya yang digunakan untuk menghasilkan output tersebut.

3) Efektivitas

Efektivitas terkait dengan hubungan antara hasil yang diharapkan dengan hasil yang sesungguhnya dicapai. Efektivitas merupakan hubungan antara output dengan tujuan. Semakin besar kontribusi output terhadap pencapaian tujuan, maka semakin efektif organisasi, program, atau kegiatan. Jika ekonomi berfokus pada input dan efisiensi pada output atau proses, maka efektivitas berfokus pada input dan efisiensi pada output dan proses, maka efektivitas berfokus pada outcome (hasil). Suatu organisasi, program, atau kegiatan dnilai efektif apabila output yang dihasilkan bisa memenuhi tujuan yang diharapkan, atau dikatakan spending wisely.

\section{Indikator Kinerja dan Pengukuran Value for Money}

Value for Money merupakan inti dari pengukuran kinerja pada organisasi pemerintahan. Kinerja pemerintahan tidak dapat dinilai dari sisi output yang dihasilkan saja, akan tetapi harus mempertimbangkan input, output dan outcome secara bersama- sama, bahkan untuk beberapa hal perlu ditambahkan pengukuran distribusi dan cakupan layanan (equity \& service coverage). Istilah ukuran kinerja pada dasarnya berbeda dengan istilah indikator kinerja. Ukuran kinerja mengacu pada penilaian kinerja secara langsung, sedangkan indikator kinerja mengacu pada penilaian kinerja secara tidak langsung, yaitu hal-hal yang sifatnya hanya merupakan indikasi-indikasi kinerja. Untuk dapat 
mengukur kinerja pemerintah, maka perlu diketahui indikator-indikator sebagai dasar penilaian kinerja. Mekanisme untuk menentukan kinerja tersebut memerlukan hal-hal sebagai berikut:

a. Sistem Perencanaan dan Pengendalian

b. Spesifikasi dan Standarisasi

c. Kompetensi Teknis dan Profesionalisme

d. Mekanisme Ekonomis dan Mekanisme Pasar

e. Mekanisme Sumber Daya Manusia

\section{Definisi Konseptual}

Definisi konseptuall bagian dari definisi-definisi yang berisi penjelasan dari konsep yang penulis gunakan dalam menganalisis kinerja berdasarkan value for money pada Dinas Kehutanan Provinsi Kalimantan Timur Kota Samarinda. Dari beberapa pendapat ahli mengenai konsep value for money, maka konsep value for money yang penulis gunakan dalam penelitian ini adalah sebagai berikut:

Menurut Mahmudi (2015:89) value for money merupakan kunci pengukuran kinerja sektor publik, maka sistem pengukuran kinerja sektor publik, maka sistem pengukuran kinerja sektor publik juga harus difokuskan untuk mengukur ekonomi, efisiensi, dan efektivitas.

Menurut Mardiasmo (2009:04) value for money merupakan konsep pengelolaan organisasi sektor publik yang mendasar pada tiga elemen utama yaitu ekonomi, efisiensi dan efektivitas. Dimana pengertian dari tiga elemen utama value for money adalah sebagai berikut:

\section{1) Ekonomi}

Merupakan pemerolehan input dengan kualitas dan kuantitas tertentu pada harga terendah. Ekonomi terkait dengan sejauh mana organisasi dapat meminimalisir input resources yang digunakan dengan menghindari pengeluaran yang boros. Input merupakan sumber daya yang digunakan untuk pelaksanaan suatu program atau kegiatan, contohnya dokter dirumah sakit, guru disekolah dan sebagainya, input juga dapat dinyatakan dengan nilai uang misalnya gaji guru, biaya dokter dan sebagainya.

\section{2) Efisiensi}

Efisiensi merupakan pencapaian output yang maklsimum dengan input tertentu atau penggunaan input yang terendah untuk mencapai output tertentu. Efisiensi merupakan perbandingan output atau input yang dikaitkan dengan standar kinerja atau target yang telah ditetapkan.

\section{3) Efektivitas}

Efektivitas merupakan tingkat pencapaian hasil program dengan target yang ditetapkan. Secara sederhana efektivitas merupakan perbandingan output dan outcome. Outcome merupakan dampak yang ditimbulkan dari suatu aktivitas tertentu. Sebagai contoh, outcome yang diharapkan terjadi dari aktivitas pengawasan hutan oleh Dinas Kehutanan adalah memelihara keutuhan hutan dan fungsinya. Outcome seringkali dikaitkan dengan tujuan (objectives) atau target yang hendak dicapai.

\section{METODE}

\section{Definisi Operasional}

Definisi Operasional dimaksudkan untuk menghindari kesalahan pemahaman dan perbedaan penafsiran yang berkaitan dengan istilah-istilah dalam judul skripsi. Sesuai dengan judul penelitian yaitu "Analisis Kinerja Kegiatan Rehabilitasi Hutan dan Lahan Berdasarkan Value For Money pada Dinas Kehutanan Provinsi Kalimantan Timur Kota Samarinda" maka definisi operasional yang perlu dijelaskan adalah sebagai berikut:

1) Dinas Kehutanan Kalimantan Timur merupakan unsur pelaksana Pemerintah Provinsi Kalimantan Timur yang berada dibawah dan bertanggung jawab kepada Gubernur. Dinas Kehutanan melaksanakan tugas perbantuan di bidang pengelolaan Hutan dan Lahan yaitu dengan mengacu pada sasaran strategis yang tercantum didalam Rencana Strategis (RENSTRA) 2013-2018. Pada tahun 2014 upaya yang dilakukan Dinas Kehutanan dalam mewujudkan sasaran strategis yaitu dengan 
merencanakan 5 Program yang terdiri dari 14 kegiatan. Program Rehabilitas merupakan salah satu dari lima kebijakan prioritas Dinas Kehutanan.

2) Kinerja merupakan hasil dari kegiatan atau program yang telah dicapai oleh Dinas Kehutanan Provinsi Kalimantan Timur. Setiap kegiatan atau program perlu dilakukan penilaian kinerja. Karena penilaian kinerja (performance appraisal) merupakan faktor kunci guna mengembangkan suatu organisasi (Dinas Kehutana n Provinsi Kalimantan Timur).

3) Value For Money (VFM) merupakan konsep penting dalam organisasi sektor publik (Dinas Kehutanan Provinsi Kalimantan Timur). Konsep Value For Money terdiri atas tiga elemen utama yaitu ekonomi, efisiensi dan efektivitas dengan konsep dasar input, output dan outcome. Dimana yang menjadi ukuran ekonomi, efisiensi dan efektivitas adalah sebagai berikut:

\section{a) Ekonomi}

Untuk menentukan nilai ekonomi dibutuhkan indikator kinerja. Yang menjadi indikator kinerja atau ukuran dalam menentukan nilai ekonomi pada Dinas Kehutanan Provinsi Kalimantan Timur yaitu Input berupa anggaran sebesar Rp4.683.790.000, Pelaksana Kegiatan, Honorarium Panitia Pelaksana Kegiatan, Belanja Perjalanan Dinas dalam daerah, Belanja perjalanan Dinas luar Daerah, Pengadaan Tanaman, Alat atau Perlengkapan, Bahan dan Bibit Tanaman, Bahan Obat-obatan, Jasa Publikasi, Belanja Cetak Laporan, Belanja Makanan dan Minuman Rapat dan Pelatihan, Pakaian Seragam tertentu, Dokumentasi, Bahan Material, Mobil Patroli, Motor Patroli, kamera dan GPS.

\section{b) Efisiensi}

Untuk menentukan nilai efisiensi dibutuhkan indikator kinerja. Yang menjadi indikator kinerja atau ukuran dalam menentukan nilai efisiensi pada Dinas Kehutanan Provinsi Kalimantan Timur yaitu Output berupa berkurangnya lahan kritis pada kawasan hutan dan lahan, rehabilitas lahan/penanaman one man five trees (HMPI), luas penanaman kawasan Hutan Mangrove dan menurunnya kegiatan ilegal logging dan perambahan hutan serta berkurangnya perdagangan hasil hutan ilegal 14 Kabupaten/Kota.

\section{c) Efektivitas}

Sedangkan untuk menentukan nilai efektivitas dibutuhkan juga Indikator Kinerja. Yang menjadi Indikator Kinerja atau ukuran dalam menentukan nilai efektivitas yaitu Outcome terlaksananya Penanaman dan Pemeliharaan pada Kawasan Hutan dan Lahan yg rusak.

\section{Rincian Data} berikut:

Untuk memepermudah peneliti yang dilakukan, maka data yang diperlukan adalah sebagai

1) Gambaran umum Dinas Kehutanan Provinsi Kalimantan Timur tahun 2014

2) Data-data untuk perhitungan kinerja program Rehabilitasi Hutan dan Lahan tahun 2014

3) LAKIP Dinas Kehutanan Provinsi Kalimantan Timur tahun 2014

\section{Jangkauan Penelitian}

Penelitian ini dilakukan pada Dinas Kehutanan Provinsi Kalimantan Timur terletak di Jl. Kesuma Bangsa Samarinda Kalimantan Timur. Penelitian ini berfokus pada data kegiatan Rehabilitasi Hutan dan Lahan Tahun 2014.

\section{Teknik Pengumpulan Data}

Teknik yang digunakan untuk mengumpulkan data dalam pelaksanaan penelitian ini adalah sebagai berikut:

1) Penelitian Lapangan (Field Work Research), yaitu kegiatan pengumpulan data yang didasarkan atas keadaan sesungguhnya di lapangan. Field Work Research dilakukan dengan dua cara yaitu :

a) Wawancara, yaitu suatu cara untuk memperoleh data dengan mengadakan wawancara langsung kepada Kepala Program dan bagian lain yang berkaitan dengan penelitian ini. 
b) Dokumentasi, yaitu pengumpulan bukti-bukti (dokumen) dengan cara membuat salinan, mencatat serta mengutip data-data dari sumber langsung, yaitu kepada bagian pelaksana program Rehabilitasi Hutan dan Lahan.

2) Penelitian Kepustakaan (Library Research), yaitu penelitian yang dilakukan dengan cara mempelajari teori dan infromasi yang erat hubungannya dengan objek penelitian sebagai pedoman pokok dalam pengumpulan data di lapangan.

\section{Alat Analisis}

Alat analisis yang digunakan dalam penelitian ini yaitu dengan menggunakan alat analisis Value For Money yang meliputi 3 hal (Mahmudi, 2010:83):

\section{HASIL DAN PEMBAHASAN}

\section{Nilai Ekonomi}

Nilai Ekonomi dari Program Kegiatan Rehabilitasi Hutan dan Lahan yang dilakukan Dinas Kehutanan Provinsi Kalimantan Timur dapat diukur dengan membandingkan input primer (dana yang terealisasi) dengan input sekunder berupa (SDM / Tim Pengadaan Saran dan Prasarana). Dari hasil perhitungan analisis Kertas Kerja Penilaian Kinerja Dinas Kehutanan Provinsi Kalimantan Timur memperoleh nilai ekonomi sebesar 89\%. Nilai Kinerja Ekonomi $85 \%$ sampai dengan $100 \%$ merupakan nilai kinerja yang masuk pada kategori Cukup Ekonomis. Dilihat dari anggaran yang terealisasi $68 \%$, Panitia Pelaksana Kegiatan terealisasi 100\%, Pelaksa Kegiatan terealiasi 160\% dikarenakan masyrakat sekitar juga turun ke lapangan, Pengadaan Bibit Tanaman terealiasi 75\% karena tidak semua jenis bibit tanaman cocok dengan kondisi Hutan. Sarana Prasarana mobil patroli 100\% serta sarana prasarana GPS terealisasi 100\%. Dari segi anggaran hanya $68 \%$.

\section{Nilai Efisiensi}

Berdasarkan hasil analisis data pengukuran efisiensi pada program kegiatan Rehabilitasi Hutan dan Lahan diketahui bahwa untuk periode tahun 2014 program kegiatan ini dapat dikatakan efisien. Pada periode tahun 2014 Dinas Kehutanan Provinsi Kalimantan Timur Kota Samarinda dalam menjalankan program kegiatan ini dapat menghasilkan output maksimal mencapai $100 \%$ dengan penggunaan input hanya 89\%. Dari hasil perhitungan analisis Kertas Kerja Penilaian Kinerja Value For Money Dinas Kehutanan Provinsi Kalimantan Timur memperoleh nilai efisiensi sebesar $116 \%$. Nilai Kinerja Efisiensi lebih besar dari 100\% merupakan nilai kinerja yang masuk pada kategori Sangat Efisien. Dari hasil perhitungan analisis Indikator Value For Money memperoleh nilai efisiensi sebesar $130 \%$. Namun pengukuran yang hanya diukur dengan kertas kerja penialaian biasa belum membandingkan anatara input, output, dan outcome. Maka perlu dilakukan penilaian dengan perhitungan kertas kerja penilaian Value for Money.

\section{Nilai Efektivitas}

Pengukuran efektivitas bertujuan untuk mengetahui kinerja Dinas Kehutanan Provinsi Kalimantan Timur Kota Samarinda dalam mencapai tujuan atau target kebijakan dari suatu program atau kegiatan yang telah ditetapkan. Hasil analisis perhitungan Kertas Kerja Penialian Kinerja Value For Money Dinas Kehutanan Provinsi Kalimantan Timur menunjukkan bahwa kinerja Dinas Kehutanan dan dari segi efektivitas efektif sedangkan dari penilaian kinerja 3E perbandingan antara outcome dan output menunjukkan bahwa Kinerja Dinas Kehutanan Provinsi Kalimantan Timur efektif. Penialain efektivitas yang dihasilkan Kegiatan ini pada periode tahun 2014 menurut Kertas Kerja Penilaian Kinerja yaitu 106\%. Dengan membandingkan anatara nilai kinerja dibagi dengan nilai kinerja output maka pendapatkan persentase tersebut. Sedangkan Penilaian efektivitas yang dihasilkan menurut Kertas Kerja Penilaian Kinerja Value For Money dengan persentase 91,37\% dengan rincian kenaikan kondisi hutan dan lahan yang baik dengan persentase $100 \%$ dan terlaksananya penanaman pohon di kawasan lahan kritis dengan target 22.445 .678 pohon dengan realisasi tingkat capaian dari hasil pengukuran terhadap indikator tersebut diperoleh 25.226 .724 pohon sehingga persentase yang dicapai pada indikator ini sebesar $112 \%$ sehingga mendapat rata-rata nilai $106 \%$. 


\section{SIMPULAN}

Penelitian ini bertujuan untuk mengetahui kinerja berdasarkan value for money pada Program kegiatan Rehabilitasi Hutan dan Lahan Dinas Kehutanan Provinsi Kalimantan TImur Kota Samarinda tahun 2014. Adapun kesimpulan berdasarkan hasil penelitian ini sebagai berikut :

1. Nilai Ekonomi dari Program Kegiatan Rehabilitasi Hutan dan Lahan yang dilakukan Dinas Kehutanan Provinsi Kalimantan Timur dapat diukur dengan membandingkan input primer (dana yang terealisasi) dengan input sekunder berupa (SDM / Tim Pengadaan Saran dan Prasarana). Dari hasil perhitungan analisis Kertas Kerja Penilaian Kinerja Dinas Kehutanan Provinsi Kalimantan Timur memperoleh nilai ekonomi sebesar 89\%. Nilai Kinerja Ekonomi $85 \%$ sampai dengan 100\% merupakan nilai kinerja yang masuk pada kategori Cukup Ekonomis. Dilihat dari anggaran yang terealisasi 68\%, Panitia Pelaksana Kegiatan terealisasi 100\%, Pelaksa Kegiatan terealiasi $160 \%$ dikarenakan masyrakat sekitar juga turun ke lapangan, Pengadaan Bibit Tanaman terealiasi $75 \%$ karena tidak semua jenis bibit tanaman cocok dengan kondisi Hutan. Namun dengan adanya salah satu yang masuk dalam kategori kurang ekonomis, tetapi kinerjanya ini dikatakan Sangat Berhasil dalam melakukan kegiatan dalam program tersebut.

2. Berdasarkan hasil analisis data pengukuran efisiensi pada program kegiatan Rehabilitasi Hutan dan Lahan diketahui bahwa untuk periode tahun 2014 program kegiatan ini dapat dikatakan efisien. Pada periode tahun 2014 Dinas Kehutanan Provinsi Kalimantan Timur Kota Samarinda dalam menjalankan program kegiatan ini dapat menghasilkan output maksimal mencapai $100 \%$ dengan penggunaan input hanya 89\%. Dari hasil perhitungan analisis Kertas Kerja Penilaian Kinerja Value For Money Dinas Kehutanan Provinsi Kalimantan Timur memperoleh nilai efisiensi sebesar $116 \%$. Nilai Kinerja Efisiensi lebih besar dari $100 \%$ merupakan nilai kinerja yang masuk pada kategori Sangat Efisien. Dari hasil perhitungan analisis Indikator Value For Money memperoleh nilai efisiensi sebesar 130\%. Dan program ini terlaksana dengan Sangat Berhasil.

3. Berdasarkan nilai efektivitas Penialain efektivitas yang dihasilkan Kegiatan ini pada periode tahun 2014 menurut Kertas Kerja Penilaian Kinerja yaitu 106\%. Dengan membandingkan anatara nilai kinerja dibagi dengan nilai kinerja output maka pendapatkan persentase tersebut.

4. Sedangkan Penilaian efektivitas yang dihasilkan menurut Kertas Kerja Penilaian Kinerja Value For Money dengan persentase 91,37\% dengan rincian kenaikan kondisi hutan dan lahan yang baik dengan persentase $100 \%$ dan terlaksananya penanaman pohon di kawasan lahan kritis dengan target 22.445 .678 pohon dengan realisasi tingkat capaian dari hasil pengukuran terhadap indikator tersebut diperoleh 25.226 .724 pohon sehingga persentase yang dicapai pada indikator ini sebesar $112 \%$ sehingga mendapat rata-rata nilai $106 \%$

5. Berdasarkan analisis perhitungan kertas kerja penilaian kinerja value for money pada program kegiatan Rehabilitasi Hutan dan Lahan Dinas Kehutanan Provinsi Kalimantan Timur masuk dalam kategori Cukup Ekonomis, dari segi Efisien masuk dalam kategori Sangat Efisien dan dari segi efektivitas masuk dalam kategori Efektif sedangkan dari segi penilaian 3E memperoleh nilai efektif. Nilai akhir yang diperoleh Bagian Program Rehabilitasi Hutan dan Lahan yaitu SANGAT BERHASIL

\section{DAFTAR PUSTAKA}

Afiati, Tri Astuti.2011. Analisis Value for Money pada Badan Perencanaan Pembangunan Daerah (BAPPEDA) Kabupaten Semarang. Skripsi. Fakultas Ekonomi Universitas Negeri Semarang.

Bastian, Indra. 2009. Akuntansi Sektor Publik di Indonesia. BPFE UGM. Yogyakarta.

Fakultas Ekonomi. 2011, Pedoman Penyusunan Skripsi. Universitas Mulawarman Samarinda. 2006. Akuntansi Sektor Publik. Erlangga, Jakarta

Handayani, Shinditya. 2014. Analisis Efisiensi Anggaran Belanja pada Dinas Pendidikan Kota Samarinda. Skripsi. Fakultas Ekonomi Universitas Mulawarman. Samarinda.

Mangkunegara, A.A Anwar Prabu. 2009. Manajemen Sumber Daya Manusia. PT.Remaja Rosdakarya, Bandung. 
Mardiasmo.2009. Akuntansi Sektor Publik. Andi, Yogyakarta.

Mahsun, Mohamad. 2014. Pengukuran Kinerja Sektor Publik. BPFE. Yogyakarta. Mahmudi. 2015. Manajemen Kinerja Sektor Publik. UPP STIM YKPN. Yogyakarta.

Nurlan, Darise. 2008. Akuntansi Keuangan Daerah (Akuntansi Sektor Publik). Indeks, Jakarta.

Notoatmojo, Soekidjo. 2009. Pengembangan Sumber Daya Manusia, Cetakan Keempat. Rineka Cipta. Jakarta.

Sedarmayanti. 2011. Manajemen Sumber Daya Manusia, Reformasi Birokrasi dan Manajemen Pegawai Negeri Sipil. Cetakan Kelima. PT. Refika Aditama.

Wibowo. 2010. Manajemen Kinerja. Edisi Ketiga.Penerbit Rajawali Pers. Jakarta. 